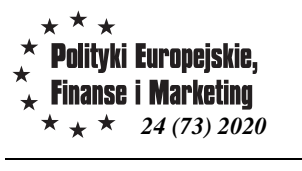

DOI 10.22630/PEFIM.2020.24.73.34

Marta Penczar

Accepted: 19.10 .2020

Monika Liszewska

Lech Kujawski

University of Gdansk

\title{
THE IMPACT OF FUNDING STRUCTURE ON EU BANKING SECTOR STABILITY
}

In our paper, we analyse the impact of funding structure on banking sector stability in EU countries. Our findings show that after the global financial crisis (GFC) there are four main funding models in the EU banking sectors. We document that funding structure is an important factor influencing the banking sector stability. We report that there are also some other banking business model characteristics as well as macroeconomic indicators which have impact on banking sector risk.

Keywords: banking sector stability, banking funding model, funding structure JEL Codes: G01, G21, G28

\section{Introduction}

The funding structure is an important element of the banking business model. The funding model mainly consists of the liabilities structure, including non-financial sector deposits, wholesale funding, debt and capital in relation to total assets. Those sources of funding differ in the cost of acquisition and the risk resulting from their stability. The significance of the funding model, however, has an important influence not only for the risk of an individual bank, but through the system of links between institutions, also for the stability of the entire banking sector.

The aim of the article is to assess the impact of bank funding models on banking sector stability in the European Union.

The first part of the article reviews the literature regarding the impact of the business model, including the funding model, for the stability of banks. The second part presents the funding structure of the EU banking sectors in 2010-2016. Additionally, this chapter analyses banking sector funding models using cluster analysis. The last part of the article refers to the assessment of the impact of the funding model on EU banking sector stability.

\section{Literature review}

The literature review indicates a differentiated approach to defining financial stability ${ }^{1}$. Financial stability can be interpreted as the lack of a negative impact on the real

${ }^{1}$ P. Niedziółka: Kredytowe instrumenty pochodne a stabilność finansowa, Oficyna Wydawnicza Szkoła Główna Handlowa, Warszawa 2011. 
economy or with the lack of a crisis ${ }^{2}$. Another approach defines financial stability as the proper functioning of the financial system, ensuring allocation, payment and asset valuation ${ }^{3}$. According to the definition of the European Central Bank, financial stability is defined as a situation in which the financial system is able to withstand shocks and solve financial imbalances ${ }^{4}$. The concept of financial stability and stability of the banking sector are often used interchangeably. This approach is supported by the significant role of the banking sector in the financial system.

Financial stability can also be considered at the microeconomic level, taking into account the perspective of a single institution. In this context, financial stability refers to the bank's risk, measured by such ratios as: value at risk (VaR), expected shortfall, capital asset pricing model (CAPM), non-performing loans to total assets ratio and Z-score ratio ${ }^{5}$. Altunbas et al. indicate that except CAPM ratio, the risk of a single bank can be measured using information about financial support provided to the bank or information about the central bank's liquidity demand reported by a given bank ${ }^{6}$.

At the same time Niedziółka points to the close connection between stability on a macroeconomic level with the stability of individual institutions ${ }^{7}$. Similarly, Jahn and Kick point out that a stable banking system should be understood as a system consisting of solvent financial institutions that meet the allocation, settlement and risk transformation functions ${ }^{8}$.

The financial crisis experienced in 2007-2008 allowed researchers to identify key factors determining a bank's risk and, consequently, the risk to the stability of the entire banking sector. The literature indicates that a bank's stability depends on the funding model (structure of a bank's liabilities), income sources (interest vs. non- interest), the size of the bank, diversification and capitalization levels.

The literature refers primarily to the analysis of changes in funding models and diversification of income sources and its impact to a bank's risk ${ }^{9}$. Taking into account the main aim of this paper we will concentrate on the funding model as a determinant of bank stability.

\footnotetext{
${ }^{2}$ C.A.E. Goodhart: A framework for assessing financial stability?, "Journal of banking \& finance", 30(2006), pp. 3415-3422.

${ }^{3}$ O. Szczepańska, P. Sotomska-Krzysztofik, M. Pawliszyn, A. Pawlikowski: Instytucjonalne uwarunkowania stabilności finansowej na przykładzie wybranych krajów, Materiały i Studia, Zeszyt Nr 173, Narodowy Bank Polski, Warszawa, 2004.

${ }^{4}$ ECB: Financial Stability Review, November 2018, s.3.

${ }^{5}$ Li X., Tripe D., Malone Ch.: Measuring bank risk: An exploration of z-score, 2017.

${ }^{6}$ Y. Altunbas, S. Manganelli, D. Marques-Ibanez: Bank risk during the financial crisis, Working Paper Series No 1394, November 2011, European Central Bank.

${ }^{7}$ P. Niedziółka, op. cit. : Kredytowe instrumenty pochodne a stabilność finansowa, Oficyna Wydawnicza Szkoła Główna Handlowa, Warszawa 2011.

${ }^{8}$ J. Nadya, T. Kick: Determinants of Banking System Stability: A Macro-Prudential Analysis, 2012.

${ }^{9}$ see L. Allen, J. Jagtiani: The Risk Effects of Combining Banking, Securities, and Insurance Activities,

"Journal of Economics and Business", 52(6), pp. 485-497, 2000, E. Davis, D. Karim: Comparing Early Warning Systems for Banking Crisis, "Journal of Financial Stability", 4(2), pp. 89-120, 2008 and O. DeJonghe: Back to the Basics in Banking? A Micro-analysis of Banking System Stability, "Journal of Financial Intermediation", 19(3), pp. 387-417, 2010.
} 
Altunbas et al. define the funding model as the share of retail deposits in total assets and the share of short-term marketable securities in total assets ${ }^{10}$. According to Köhler, it can be calculated as the share of non-deposit sources in liabilities ${ }^{11}$. Similarly, Demirgüç-Kunt and Huizinga analysed the funding model through the prism of nondeposit financing sources, however, in relation to short-term financing ${ }^{12}$.

Ayadi and De Groen indicate that banks based on the traditional, deposit-based funding model are smaller and have a lower share of non-interest income ${ }^{13}$. In turn, banks that depend on wholesale funding are larger and more active on the capital market and involved in commercial activities. Altunbas et al. documented that banks which are more dependent on wholesale sources were more likely to fail during the crisis ${ }^{14}$. On the other hand, banks with a more diversified income structure proved to be more stable.

Demirgüc-Kunt and Huizinga, studying the impact of income and funding models on the profitability and the bank's risk, noted that only a few institutions could reduce the risk in the case of diversification of funding or income ${ }^{15}$. A positive effect can only occur in banks with a low level of non-interest income and non-deposit sources. In general, however, the increase in the non-deposit funding and non-interest income is associated with greater instability. In turn, Wagner ${ }^{16}$ and Brunnermeier et al. ${ }^{17}$ prove that bank entry into activity other than deposits and loans will allow for the diversification of individual risk, but may generate systemic risk.

Köhler's research shows that an increase in the stability of retail traditional banks (higher level of Z-score) can take place in the context of the growing importance of noninterest income resulting from the diversification of income ${ }^{18}$. In the case of investment banks, it will be the opposite, that is, they will be less stable. But in turn, the increase in non-deposit funding will be detrimental to retail-oriented banks and increase the bank's risk.

This means that reducing a bank's risk requires adjusting the activities depending on the funding model and sources of income. Investment-oriented banks, through increased interest income, may be more stable as a result of limiting the risk of overdiversification. Further dependence on non-interest income means more volatile income for the bank, which will translate into an increase in systemic risk.

Based on literature review, our main research hypotheses are:

${ }^{10}$ Y. Altunbas, S. Manganelli, D. Marques-Ibanez: Bank risk during the financial crisis, Working Paper Series No 1394, November 2011, European Central Bank.

${ }^{11}$ M. Köhler: Which banks are more risky? The impact of business models on bank stability, ,Journal of Financial Stability”, 16(2015), pp. 195-212.

${ }^{12}$ A. Demirgüç-Kunt, H. Huizinga: Bank Activity and funding strategies: The impact on risk and returns, "Journal of Financial Economics", 98(2010), pp. 626-650.

${ }^{13}$ R. Ayadi, W.P. De Groen: Banking Business Models Monitor 2015: Europe, 2015.

${ }^{14}$ Y. Altunbas, S. Manganelli, D. Marques-Ibanez: Bank risk during the financial crisis, Working Paper Series No 1394, November 2011, European Central Bank.

${ }^{15}$ A. Demirgüç-Kunt, H. Huizinga: Bank Activity and funding strategies: The impact on risk and returns, "Journal of Financial Economics", 98(2010), pp. 626-650.

${ }^{16}$ W. Wagner: The Liquidity of Bank Assets and Banking Stability, "Journal of Banking and Finance", 31(1), pp. 121-39, 2007.

${ }^{17}$ M.K. Brunnermeier, G. Dong, D. Palia: Banks' Non-Interest Income and Systemic Risk, AFA 2012 Chicago Meetings Paper, 2012.

${ }^{18}$ M. Köhler: Which banks are more risky? The impact of business models on bank stability, "Journal of Financial Stability", 16(2015), pp. 195-212. 
- H1: The banking sectors in the EU are characterised by different funding models.

- H2: The funding model has a significant impact on the level of stability of the banking sector.

- H3: Household deposits play a stabilizing role in increasing the security of the banking sector.

- H4: The increase in the share of non-deposit funding has a negative impact on the stability of the banking sector.

Our contribution to literature is as follows: Firstly, we identify factors determining banking sector stability during and after GFC. Secondly, we analyse the impact of the funding model on the financial stability not from individual banks' point of view, but from the banking sector perspectives.

The article was prepared as part of a project financed by the National Science Centre entitled "The structure of the banking sector's funding sources and the domestic banking sector stability in the context of new regulatory initiatives" (contract number: UMO-2016/23 / B / HS4 / 03220).

\section{Funding models in EU banking sectors}

The banking sectors in the EU were grouped according to the structure of liabilities. Liability structure data come from European Central Bank database (Consolidated Banking Data). Due to the data availability, the analysis includes 24 national sectors from the $\mathrm{EU}^{19}$. As we wanted to check the funding models in post-crisis banking sectors, we focused on the period 2010-2016. It enabled us to analyse the current funding models used in the European sectors.

The analysis of funding models in EU banking sectors was conducted with the use of a numerical taxonomy. Based on the liability structure a cluster analysis was carried out $^{20}$. The cluster analysis indicates that there are four funding models in EU banking sectors, which confirms our first research hypothesis. The first model (Model A) is characterized by a high share of deposits from the non-financial sector in the funding structure. Both the household deposits and non-financial deposits to total assets ratios are much above the EU average. In addition, there is a high level of capital and reserves in relation to total assets in Model A. At the same time, the banking sectors from this group are characterized by a low share of external liabilities and a low share of debt in the funding structure. Model A is typical for the following countries: Bulgaria, Czech Republic, Lithuania, Poland, Romania and Slovakia. In banking sectors which represent Model B there is a significant share of external liabilities in the funding structure. The

\footnotetext{
${ }^{19}$ Austria, Belgium, Bulgaria, Cyprus, Czech Republic, Finland, France, Spain, Holland, Ireland, Lithuania, Luxembourg, Latvia, Malta, Germany, Poland, Portugal, Romania, Slovakia, Slovenia, Sweden, Hungary, Great Britain, Italy.

${ }^{20}$ The average for years 2010-2016 of the following variables was used: ratio of household deposits to total assets (HHDepo2TA_10-16), ratio of non-financial corporations deposits to total assets (nFIN2TA_10-16), ratio of debt to total assets (Dt2TA_10-16), ratio of MFI deposits to total assets (MIF2TA_10-16), ratio of capital and reserves to total assets (Cap2TA_10-16) and ratio of external liabilities to total assets (EL2TA_1016).
} 
ratio of external liabilities to total assets is much above the EU average. This model occurs in Ireland, Luxemburg, Latvia, Malta and United Kingdom.

The third model, Model C, is typical for Finland, The Netherlands and Sweden. It is determined by a high level of debt in relation to total assets, which is much above the EU average. Moreover, Model $\mathrm{C}$ is characterized by the high level of external liabilities to total assets ratio.

Table 1. Main characteristics of funding models in EU banking sectors

\begin{tabular}{|c|c|c|}
\hline Model & EU banking sectors & Characteristics \\
\hline A & $\begin{array}{l}\text { Bulgaria, Czech } \\
\text { Republic, Lithuania, } \\
\text { Poland, Romania, } \\
\text { Slovakia, }\end{array}$ & $\begin{array}{l}\text { The ratio of household deposits to total assets above the EU } \\
\text { average } \\
\text { The ratio of non-financial corporation deposits to total assets } \\
\text { above the EU average } \\
\text { - High level of capital and reserves in relation to total assets } \\
\text { (above EU average) } \\
\text { The share of debt in funding structure much below the EU } \\
\text { average } \\
\text { - Very low share of MFI deposits in the funding structure }\end{array}$ \\
\hline B & $\begin{array}{l}\text { Ireland, Luxsemburg, } \\
\text { Latvia, Malta, United } \\
\text { Kingdom }\end{array}$ & $\begin{array}{l}\text { - The ratio of external liabilities to total assets much above the } \\
\text { EU average } \\
\text { - } \quad \text { Low share of debt in the funding structure }\end{array}$ \\
\hline $\mathrm{C}$ & $\begin{array}{l}\text { Finland, Netherlands, } \\
\text { Sweden }\end{array}$ & $\begin{array}{l}\text { - High level of external liabilities to total assets ratio } \\
\text { - } \quad \text { The share of debt in the funding structure above the EU average } \\
\text { - } \quad \text { Low level of household deposits to total assets ratio } \\
\text { - } \quad \text { Capital and reserves in relations to total assets below EU } \\
\text { - } \quad \text { Lowerage }\end{array}$ \\
\hline D & $\begin{array}{l}\text { Austria, Belgium, } \\
\text { Cyprus, France, Spain, } \\
\text { Germany, Portugal, } \\
\text { Slovenia, Hungary, Italy }\end{array}$ & $\begin{array}{l}\text { The ratio of household deposits to total assets at EU average } \\
\text { level } \\
\text { - The ratio of MFI deposits to total assets at EU average level }\end{array}$ \\
\hline
\end{tabular}

Source: authors' own elaboration

Model D can be observed in Austria, Belgium, France, Spain, Germany, Portugal, Slovenia, Italy, Hungary and Cyprus. It is characterized by the household deposits to total assets ratio at the EU average level. Also the share of MFI deposits in the funding structure is on the EU average.

\section{The impact of funding structure on banking sector stability}

\section{Data and methodology}

To identify factors determining the banking sector stability we use two types of data. We include banking sector characteristics from the ECB database ${ }^{21}$ and the World Bank. Additionally, we use macroeconomic variables from the $\mathrm{IMF}^{22}$ and European Commission $^{23}$. We concentrate on the 2008-2017 period, to capture the factors determining the stability of banking sectors during and directly after the crisis. This data

\footnotetext{
${ }^{21}$ Consolidated Banking Data - CBD2.

${ }^{22}$ International Monetary Fund.

${ }^{23}$ Macro-economic database AMECO, European Commission.
} 
consists of eight variables for 27 EU banking sectors. This resulted in 2160 observations for the period from 2008 to 2017.

Based on the literature we use the Z-score ratio as a dependent variable ${ }^{24}$. Z-score is defined as a measure of a bank's capital level in relation to the volatility of its returns ${ }^{25}$. It is calculated as a sum of ROA and equity to asset ratio divided by the standard deviation of ROA. Thus we can say that Z-score measures the probability of default ${ }^{26}$. However, due to the characteristics of the study, we used World Bank indicators calculated for the entire banking sectors, not for individual banks. At the macroeconomic level, the higher the value of the Z-score ratio, the lower the risk of the banking sector.

Bank default risk can be described by many factors related to business model and funding structure. Based on a literature review (i.a Kok et al. ${ }^{27}$ and Altunbas et al. ${ }^{28}$ ) we used the set of indicators as potential regressors, mainly from the following categories: funding structure, asset structure, income structure, and macroeconomic environment:

- $\quad$ funding structure

○ household deposits to total assets ratio (HHDepo2TA) - ambiguous impact, but banks with a stable deposit base should be more resistant to market turmoil;

- debt securities (DebtSec) - as one of the non-deposit funding ratios; banks with higher dependence on non-deposit sources of funding should be characterized by lower stability ratios ${ }^{29}$;

- $\quad$ income structure

○ fees and commissions to income ratio (FeeCommission2Income) - banks with higher share of non-interest income should be less stable ${ }^{30}$;

- $\quad$ asset structure

- logarithm of total assets $(\log (\mathrm{TA}))$ - equivalent of bank's size; effects of economies of scale should results in reduced risk levels for larger banks, although the impact of "too big to fail" on the bank's risk cannot be overlooked;

- loans to total assets ratio (Loans2TA) - an indicator that explains the commitment to the bank's traditional or investment activity;

- macroeconomic environment

\footnotetext{
${ }^{24}$ see M. Köhler: Which banks are more risky? The impact of business models on bank stability, "Journal of Financial Stability", 16(2015), pp. 195-212., F. Mergaerts, R. Vander Vennet: Business models and bank performance: A long-term perspective, "Journal of Financial Stability”, 22(2016), pp. 57-75 and A. DemirgüçKunt, H. Huizinga: Bank Activity and funding strategies: The impact on risk and returns, "Journal of Financial Economics", 98(2010), pp. 626-650.

${ }^{25}$ X. Li, D. Tripe, Ch. Malone: Measuring bank risk: An exploration of z-score, 2017.

${ }^{26}$ F. Strobel: Bank insolvency risk and Z-score measures with unimodal returns, Applied Economics Letters. 18. 1683-1685. 10.1080/13504851.2011.558474, 2011.

${ }^{27}$ Ch. Kok, C. Móré, M. Petrescu: Recent Trends in Euro Area Banks' Business Models and Implications for Banking Sector Stability, Financial Stability Review, European Central Bank, vol. 1, 2016.

${ }^{28}$ Y. Altunbas, S. Manganelli, D. Marques-Ibanez:, Bank risk during the financial crisis, Working Paper Series No 1394, November 2011, European Central Bank.

${ }^{29}$ R. Huang, L. Ratnovski, The dark side of bank wholesale funding, Journal of Financial Intermediation, 20, 2010, 248-263; Acharya, V. V., Gale, D., Yorulmazer, T., Rollover Risk and Market Freeze, Journal of Finance 66, 2011, 1177-1209.

${ }^{30}$ Y. Altunbas, S. Manganelli, D. Marques-Ibanez:, Bank risk during the financial crisis, Working Paper Series No 1394, November 2011, European Central Bank.
} 
○ GDP growth (GDP_GR) - higher growth results mostly in lower banking sector distress $^{31}$;

o inflation (Inf) - the impact of macroeconomic variables on a bank's risk is related to the economic expectations of lenders.

To determine the impact of funding structure on banking sector stability we estimate the following regression model: $y_{t i}=f\left(x_{t i}, \xi_{t i}\right)$.

The dependent variable $\left(\mathrm{y}_{\mathrm{it}}\right)$ is $\mathrm{Z}$-score in year $\mathrm{t}$, while $\mathrm{i}$ identifies the individuals (i.e. countries), $\mathrm{x}_{\mathrm{ti}}$ represents a set of independent variables, including both the banking sector characteristics and macroeconomic variables. Descriptive statistics are presented in Table 2.

Table 2. Selected variables and descriptive statistics

\begin{tabular}{|c|c|c|c|c|c|c|}
\hline Label & Definition & $\begin{array}{l}\text { Expected } \\
\text { sign }\end{array}$ & $\begin{array}{l}\text { Source } \\
\text { of data }\end{array}$ & Mean & $\begin{array}{l}\text { Std. } \\
\text { dev. }\end{array}$ & Median \\
\hline \multicolumn{7}{|c|}{ Dependent variable } \\
\hline $\begin{array}{l}\text { Default risk (Z- } \\
\text { score) }\end{array}$ & $\begin{array}{l}\text { Ratio of the ROA } \\
\text { plus equity to } \\
\text { assets ratio } \\
\text { divided by the } \\
\text { standard deviation } \\
\text { of the ROA }\end{array}$ & $\mathrm{x}$ & $\begin{array}{l}\text { World } \\
\text { Bank }\end{array}$ & 11,61 & 7,62 & 9,16 \\
\hline \multicolumn{7}{|c|}{ Independent variables } \\
\hline $\begin{array}{l}\text { Deposit funding } \\
\text { (HHDepo2TA) }\end{array}$ & $\begin{array}{l}\text { Share of } \\
\text { household } \\
\text { deposits in total } \\
\text { assets }\end{array}$ & + & $\begin{array}{l}\text { Own based } \\
\text { on ECB }\end{array}$ & 0,24 & 0,11 & 0,23 \\
\hline $\begin{array}{l}\text { Non-deposits } \\
\text { funding } \\
\text { (DebtSec) }\end{array}$ & $\begin{array}{l}\text { The volume of } \\
\text { debt securities } \\
\text { (mln euros) }\end{array}$ & - & $\mathrm{ECB}$ & 221439 & 353880 & 22553 \\
\hline $\begin{array}{l}\text { Income } \\
\text { structure } \\
\text { (FeeCommissio } \\
\text { n2Income) }\end{array}$ & $\begin{array}{l}\text { Fees and } \\
\text { commissions to } \\
\text { income ratio }(\%)\end{array}$ & - & ECB & 25,02 & 9,15 & 24,06 \\
\hline $\begin{array}{l}\text { Bank size } \\
(\log (\mathrm{TA}))\end{array}$ & $\begin{array}{l}\text { Logarithm of total } \\
\text { assets }\end{array}$ & $+/-$ & ECB & 12,87 & 1,85 & 13,01 \\
\hline $\begin{array}{l}\text { Credit activity } \\
\text { (Loans2TA) }\end{array}$ & $\begin{array}{l}\text { Loans to total } \\
\text { assets ratio }(\%)\end{array}$ & - & $\begin{array}{l}\text { Own based } \\
\text { on ECB }\end{array}$ & 42,51 & 15,42 & 44,39 \\
\hline $\begin{array}{l}\text { Economic } \\
\text { situation } \\
\text { (GDP_GR) } \\
\end{array}$ & GPD growth $(\%)$ & + & $\begin{array}{l}\text { AMECO } \\
\text { EC }\end{array}$ & 1,19 & 3,80 & 1,78 \\
\hline $\begin{array}{l}\text { Price stability } \\
\text { (Inf) }\end{array}$ & Inflation (\%) & - & IMF & 1,83 & 2,12 & 1,45 \\
\hline
\end{tabular}

Source: authors' own elaboration

Given that the presented model is a static one, and also due to the fact that it does not contain any endogenous variable as the explanatory variable included in the $x_{t i}$ matrix, the empirical models were estimated via "within" linear panel data (i.e. OLS) estimator $^{32}$. The general-to-specific modelling approach ${ }^{33}$ was adopted to find the final

${ }^{31}$ B. Gonzales-Hermosillo, H. Oura, Changes in bank funding patterns and financial stability risks, in Global Financial stability report: Transition challenges to stability, IMF (2013).

${ }^{32}$ Y. Croissant, G. Millo: Panel Data Econometrics in R: The plm Package, Vol. 27, Issue 2, 2008. 
(i.e. significant) set of explanatory variables. The plm package: Linear Models for Panel Data operating in the $\mathrm{R}$ environment was used for modelling and testing purposes. ${ }^{34}$ The ready-made tests and estimators available in this package were used.

The testing procedure consists of six steps. Firstly, the poolability of the data was tested. This was done to answer the question whether the models' structural parameters should be considered identical for each country of interest. In the second step the significance of individual and time effects was tested in order to determine whether oneor two-way models should be adopted. For this purpose, the procedure proposed by Honda was performed ${ }^{35}$. Then testing the type of effects was undertaken using the Hausman test ${ }^{36}$. As the data from the population rather than data from a sample were used, the preference should be to use fixed effects rather than random effects. In the next step we estimated models using the "within" linear panel data estimator and the generalto-specific strategy to identify the set of significant variables ${ }^{37}$. Finally, we tested the properties of the error term and made inferences from the model, in particular inferences about the significance of model parameters.

\section{Empirical results}

As the main objective of this paper is to identify the impact of funding model on banking sector stability, we primarily focus on variables connected with funding structure. Research results indicate that there are two statistically significant variables from the liability side of the banking sectors' balance sheet: household deposits to total assets ratio (HHDepo2TA) and debt securities volume (DebtSec), which is in line with our hypothesis (H2).

As we expected, the share of household deposits in the funding structure has a positive impact on the dependent variable, while the impact of the volume of debt securities is negative. These results are consistent with our research hypotheses $(\mathrm{H} 3$, H4). Household deposits are considered as a stable source of funding, which should lead to a lower risk of the entire banking sector. In line with this, Demirgüc-Kunt and Huizinga ${ }^{38}$ prove a greater instability of banks which are dependent on non-deposits sources of funding. Similarly, Ayadi and de Groen ${ }^{39}$ point out that retail-oriented banks are characterised by a lower risk of insolvency. It should be emphasized however, that according to literature, the impact of funding structure on the stability of banks is not clear. Calomiris indicates that wholesale funding contributes to reducing the bank's weakness through better monitoring ${ }^{40}$. This is because the price of non-deposit funding quickly adapts to the bank's risk.

\footnotetext{
${ }^{33}$ B. Baltagi: Econometric Analysis of Panel Data. 5th edition. John Wiley and Sons ltd, 2013.

${ }^{34}$ The plm package: Linear Models for Panel Data operating in the R environment is available at https://cran.rproject.org/package $=$ plm

${ }^{35}$ Y. Honda: Testing the Error Components Model With Non-Normal Disturbances, "Review of Economic Studies, 52(4), 1985, 681-690.

${ }^{36}$ J. Hausman: Specification Tests in Econometrics. Econometrica, 46(6), 1978, 1251-1271.

${ }^{37}$ Y. Croissant, G. Millo: Panel Data Econometrics in R: The plm Package, Vol. 27, Issue 2, 2008.

${ }^{38}$ A. Demirguc-Kunt, H. P. Huizinga, Bank activity, and funding strategies: The impact on risk and return, Journal of Financial Economics, 98(3), 2010, 626-650.

${ }^{39}$ R. Ayadi, W. de Groen, Banking business models monitor 2014 - Europe, Centre for European Policy

Studies and International Observatory on Financial Services Cooperatives, 2014.

${ }^{40}$ C.W. Calomiris: Building an incentive-compatible safety net, Journal of Banking and Finance, 23,1499_ $1519,1999$.
} 
Table 3. Empirical results - baseline model ${ }^{41}$

\begin{tabular}{|c|c|c|c|c|c|}
\hline \multicolumn{6}{|c|}{ Balanced Panel: $n=27, T=5-10, N=260$} \\
\hline \multicolumn{6}{|c|}{ Residuals: } \\
\hline Min. & Lst Qu. & Median & & $3^{\text {rd }} \mathrm{Qu}$. & Max. \\
\hline-9.176010 & -1.105622 & -0.013589 & & 1.079581 & 10.401820 \\
\hline \multicolumn{6}{|l|}{ Coefficients: } \\
\hline & Estimate & Std.Error & t-value & \multicolumn{2}{|l|}{$\operatorname{Pr}(>|t|)$} \\
\hline HHDepo2TA & 15,057 & 5,0662 & 2,9721 & 0,0032780 & *** \\
\hline Log_TA & $-2,7125$ & 1,4407 & $-1,8827$ & 0,0610260 &. \\
\hline FeeCommission2Income & $-0,079705$ & 0,020674 & $-3,8553$ & 0,0001507 & $* * *$ \\
\hline DebtSec & $-0,000007889$ & 0,0000023763 & $-3,3199$ & 0,0010496 & $* *$ \\
\hline Loans2TA & 0,12774 & 0,038383 & 3,3282 & 0,0010205 & $* *$ \\
\hline GDP_GR & 0,28459 & 0,045112 & 6,3084 & 0,00000000149 & $* * *$ \\
\hline Inf & $-0,3109$ & 0,086783 & $-3,5826$ & 0,0004166 & **** \\
\hline \multicolumn{6}{|c|}{---} \\
\hline \multicolumn{6}{|c|}{ 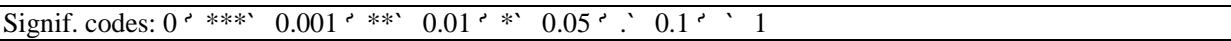 } \\
\hline
\end{tabular}

Source: based on ECB, World Bank, IMF and European Commission data.

The level of banking sector risk is also influenced by income diversification measured by the fees and commissions to income ratio (FeeCommission2Income). An increase in non-interest income in the income structure lowers the Z-score and thus increases default risk. This can be explained by a greater volatility of non-interest income in comparison with interest income.

We also include in our model two control variables: the size of the banking sector measured by the logarithm of total assets and the loans to total assets ratio. According to our research the increase in the size of the banking sector translates into a decrease in its stability as measured by the Z-score. In large banking sectors there are many more investment banks that have a higher level of risk. It is worth pointing out that at the microeconomic level, the size of an individual bank has a positive effect on reducing the risk of bankruptcy ${ }^{42}$. On the other hand, the positive impact of the loans to total assets ratio on the banking sector Z-score indicates that from the stability point of view, banks that run simple banking activity generate lower default risk.

As mentioned before, we also include in our model two macroeconomic variables: GDP growth (GDP_GR) and inflation (Inf). We prove that banking sector stability is positively correlated with GDP growth and negatively with inflation. Those results are consistent with the previous research. Köhler ${ }^{43}$ indicates that banks which operate in countries with a higher level of economic development have not only higher capital ratio but also better profitability ratios. The negative impact of inflation on banking sector stability results from the positive relation between price stability and the share of fees and commissions in income structure ${ }^{44}$.

\footnotetext{
${ }^{41}$ Total Sum of Squares: 2066.4; Residual Sum of Squares: 1183.4; R-Squared: 0.4273; F-statistic: 24.0891 on 7 and 226 DF, p-value: 2.22e-16; Poolability test: 18.099 [0.000] (stat[prob]); Individual effects: 26.030 [0.000] (stat[prob]); Time effects: -0.434 [0.668] (stat[prob]); Hausmann test: 34.860 [0.000] (stat[prob];.

${ }^{42}$ F. Mergaerts, R. Vander Vennet: Business models and bank performance: A long-term perspective, "Journal of Financial Stability", 22(2016), pp. 57-75.

${ }^{43}$ M. Köhler, Which banks are more risky? The impact of business models on bank stability, "Journal of Financial Stability", 16 (2015), 195-212.

${ }^{44}$ A. Demirgüç-Kunt, H. Huizinga: Bank Activity and funding strategies: The impact on risk and returns, "Journal of Financial Economics", 98(2010), pp. 626-650.
} 


\section{Robustness check}

To avoid drawing misleading conclusions, we have performed a robustness check to confirm the stability of the results. As already mentioned in the section containing the description of the research methodology, owing to the static nature of the models estimated and tested, and also owing to the exogenous nature of explanatory variables, model estimation was based on "within" OLS panel data estimator.

Since the aim of the study is to identify factors which determine the banking sector stability measured by Z-score, it is of particular importance that the results of individual significance tests obtained from Model (1), or at least signs of estimated parameters, be confirmed using a model estimated with an estimator other than that used in Model (1).

It was proposed that a GMM (generalized method of moments) estimator be applied to a model constructed on the basis of Model (1), which automatically entails the use of a different estimation error estimator and, as a result, generates different individual significance test statistics ${ }^{45}$. If the results of significance tests are confirmed, this may be treated as confirmation of the results previously obtained, that is, independent of the estimation method used. In order for a GMM estimator to be used, original explanatory variables should be replaced by its instruments, and lagged terms were treated as instrumental variables to the originals.

Table 4. Robustness check ${ }^{46}$

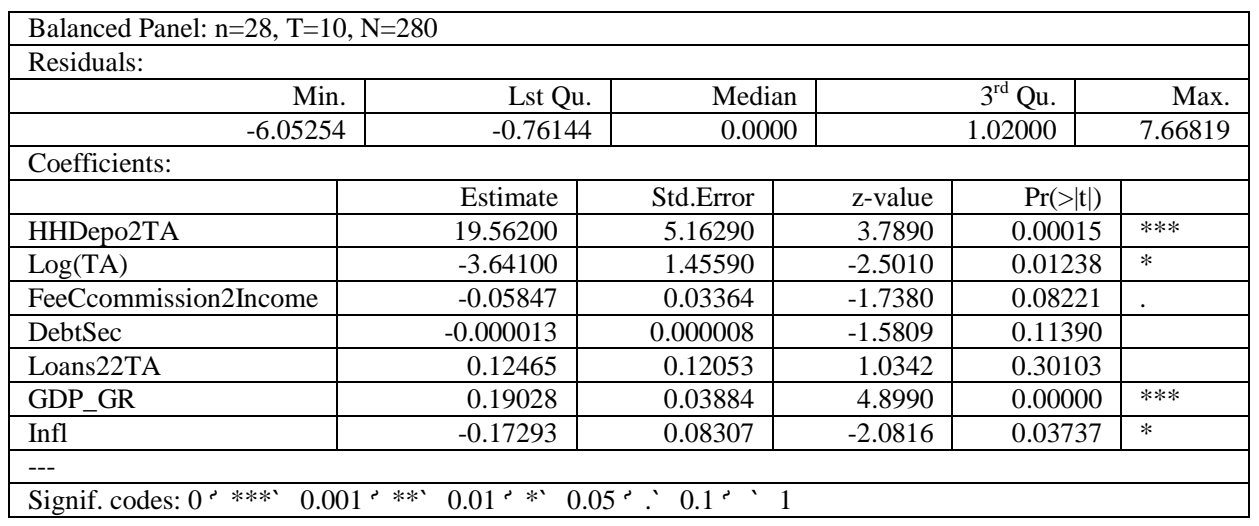

Source: based on ECB data

It should be noted that the GMM estimated version of Model (1), i.e. the estimated Model (2), confirms the results previously obtained (cf. Model (1)): parameter estimate signs are consistent for both models and (except two variables) significance test results are consistent. Obviously, Model (2) fits empirical data less well due to the replacement of original variables by its instruments

${ }^{45}$ R. Blundell, S. Bond: Initial conditions and moment restrictions in dynamic panel data models, "Journal of Econometrics", 87(1998).

${ }^{46}$ Sargan test: $\operatorname{chisq}(26)=14.82811(\mathrm{p}$-value $=1)$; Wald test for coefficients: chisq $(7)=105.7395(\mathrm{p}$-value $=$ $<2.22 \mathrm{e}-16)$. 
As concerns the comparison between the results of both estimates, it should be stated that the results obtained (parameter signs, significance of variables) do not depend on the estimation methods used and are to some extent resilient to changes in model specifications.

\section{Discussion and conclusions}

In this paper, we analyse the impact of business models on EU banking sector stability, which can be measured by the Z-score ratio. We concentrate in particular on the funding structure as a main determinant of the business model. There is no doubt that the financial crisis affected the EU banking sectors' funding structure. We documented that after GFC there can be distinguished four main funding models. These models differ in the share of customer deposits, MFI deposits, debt and capital in total assets.

Moreover the research indicates that the funding structure is one of the important factors influencing banking sector stability in the EU. Z-score ratio in the selected EU countries was positively correlated with household deposits to total assets ratio and negatively with volume of debt securities.

There is important evidence that banking sector stability is influenced also by other variables connected with the business model, i.e. net fees and commissions to income ratio, the size of banking sector measured by logarithm of total assets and loans to total assets ratio. We regard our study as a starting point for further research devoted to the influence of funding models on stability of individual banks after GFC.

\section{Bibliografia}

Allen, L., Jagtiani, J.: The Risk Effects of Combining Banking, Securities, and Insurance Activities, "Journal of Economics and Business", 52(6), pp. 485-497, 2000.

Altunbas Y., Manganelli S., Marques-Ibanez D.: Bank risk during the financial crisis, Working Paper Series No 1394, November 2011, European Central Bank.

Ayadi, R., De Groen, W. P.: Banking Business Models Monitor 2015: Europe, 2015.

Baltagi, B.: Econometric Analysis of Panel Data. 5th edition. John Wiley and Sons ltd. 2013.

Blundell R., Bond S.: Initial conditions and moment restrictions in dynamic panel data models, "Journal of Econometrics", 87, 1998.

Brunnermeier, M. K., Dong, G., Palia, D.: Banks ' Non-Interest Income and Systemic Risk, AFA 2012 Chicago Meetings Paper, 2012.

Calomiris C.W. : Building an incentive-compatible safety net, "Journal of Banking and Finance", 23,1499-1519, 1999.

Croissant Y., Millo G.: Panel Data Econometrics in R: The plm Package, Vol. 27, Issue 2, 2008.

Davis, E., Karim, D.: Comparing Early Warning Systems for Banking Crisis, "Journal of Financial Stability", 4(2), pp. 89-120, 2008.

DeJonghe, O.: Back to the Basics in Banking? A Micro-analysis of Banking System Stability, "Journal of Financial Intermediation", 19(3), 2010, pp. 387-417.

Demirgüç-Kunt A., Huizinga H.: Bank Activity and funding strategies: The impact on risk and returns, "Journal of Financial Economics", 98, 2010, pp. 626-650.

ECB: Financial Stability Review, November 2018.

Gonzales-Hermosillo B., Oura H., Changes in bank funding patterns and financial stability risks, in Global Financial stability report: Transition challenges to stability, IMF (2013).

Goodhart C.A.E.: A framework for assessing financial stability?, "Journal of banking \& finance", 30, 2006, pp. 3415-3422.

Hausman, J.: Specification Tests in Econometrics. Econometrica, 46(6), 1978, 1251-1271. 
Honda Y.: Testing the Error Components Model With Non-Normal Disturbances, "Review of Economic Studies, 52(4), 1985, 681-690.

Huang, R., Ratnovski, L., The dark side of bank wholesale funding, Journal of Financial Intermediation, 20, 2010, 248-263; Acharya, V. V., Gale, D., Yorulmazer, T., Rollover Risk and Market Freeze, Journal of Finance 66, 2011, 1177-1209.

Köhler M.: Which banks are more risky? The impact of business models on bank stability, "Journal of Financial Stability", 16, 2015, pp. 195-212.

Kok Ch., Móré C., Petrescu M.: Recent Trends in Euro Area Banks' Business Models and Implications for Banking Sector Stability, "Financial Stability Review, European Central Bank, vol. 1, 2016.

Li X., Tripe D., Malone Ch.: Measuring bank risk: An exploration of z-score, 2017.

Mergaerts F., Vander Vennet R.: Business models and bank performance: A long-term perspective, "Journal of Financial Stability", 22, 2016, pp. 57-75.

Nadya J., Kick T.: Determinants of Banking System Stability: A Macro-Prudential Analysis, 2012.

Niedziółka P.: Kredytowe instrumenty pochodne a stabilność finansowa, Oficyna Wydawnicza Szkoła Główna Handlowa, Warszawa, 2011.

Strobel F.: Bank insolvency risk and Z-score measures with unimodal returns, Applied Economics Letters. 18. 1683-1685. 10.1080/13504851.2011.558474, 2011.

Szczepańska O., Sotomska-Krzysztofik P., Pawliszyn M., Pawlikowski A.: Instytucjonalne uwarunkowania stabilności finansowej na przykładzie wybranych krajów, "Materiały i Studia", Zeszyt Nr 173, Narodowy Bank Polski, Warszawa 2004.

Wagner, W.: The Liquidity of Bank Assets and Banking Stability, "Journal of Banking and Finance", 31(1), pp. 121-39, 2007.

\section{The impact of funding structure on EU banking sector stability}

\section{Summary}

In our article, we analyze the impact of the funding structure on the banking sector stability in EU countries. Our findings show that after the GFC, there are four main funding models in EU banking sectors. We document that the funding structure is an important factor determining the stability of the banking sector. We point out that there are other features of the banking business model as well as macroeconomic indicators that influence the banking sectors risk.

Key words: banking sector stability, banking funding model, funding structure JEL Codes: G01, G21, G28

Information about author:

Marta Penczar, Ph.D.

Faculty of Management, University of Gdansk

Armii Krajowej Str. 101, Sopot, Poland

e-mail: marta.penczar@ug.edu.pl

ORCID: 0000-0002-3564-1460

Monika Liszewska, MSc

Faculty of Management, University of Gdansk

Armii Krajowej Str. 101, Sopot, Poland e-mail: monika.liszewska@phdstud.ug.edu.pl ORCID: 0000-0002-7714-602X

Lech Kujawski, Ph.D.

Faculty of Management, University of Gdansk

Armii Krajowej Str. 101, Sopot, Poland

e-mail: lech.kujawski@ug.edu.pl

ORCID: 0000-0001-5738-1180 